\title{
How Balinese Adolescents Perceived Romantic Relationship
}

\author{
Dewi Arum Widhiyanti Metra Putri ${ }^{\left.1^{*}\right)}$, Kwartarini Wahyu Yuniarti ${ }^{2}$, Wenty Marina \\ Minza $^{3}$, Bagus Riyono ${ }^{4}$ \\ ${ }^{1}$ Ganesha University of Education, Singaraja, 81116, Bali, Indonesia \\ ${ }_{1,2,3,4}$ Center for Indigenous and Cultural Psychology, Faculty of Psychology, Gadjah Mada \\ University, Sleman, 55281, Daerah Istimewa Yogyakarta, Indonesia
}

*) Corresponding author: dewiarum.wmp@undiksha.ac.id

\begin{abstract}
The romantic relationship is an interesting topic to study because it emerges as an important part of adolescent development that becomes increasingly important in subsequent years of individual development. One of the limitations of research in this field is the difficulty of providing unique and standards definitions of romantic relationships due to cultural differences in conceptions and the differences within individuals from the same cultural group. This study aims to explore the concept of a romantic relationship from the perceptions of Balinese adolescents and terms that represent it that can be used as a basis to comprehend the dynamics of romantic relationships in Balinese culture nowadays. Two phases of the study conducted through survey and FGD. Balinese adolescents were aged $15-17$ years old $(n=277)$. Through thematic analysis procedures, some emergent themes were identified as romantic relationship conceptualization. This relationship was conceptualized as an exclusive relationship, consisting of affective, cognitive, and psychomotor dimensions, and was represented by many terms. This study concluded that the concept of romantic relationships for each individual from the same cultural group could be perceived differently, leading to varied forms of adolescents' behavior.
\end{abstract}

Keywords: adolescent, Balinese, concept, perception, romantic relationship

\begin{abstract}
Abstrak
Relasi romantis adalah topik yang menarik untuk dikaji karena muncul sebagai bagian penting dari perkembangan remaja yang memegang peranan penting dalam tahap-tahap perkembangan selanjutnya dari individu. Salah satu keterbatasan penelitian di bidang ini adalah adanya kesulitan untuk menyediakan definisi yang unik dan terstandar dari relasi romantis yang disebabkan karena perbedaan budaya dalam hal konsepsi dan perbedaan individu yang berasal dari budaya yang sama. Tujuan penelitian ini adalah untuk menggali konsep relasi romantis dari persepsi remaja suku Bali dan istilah yang merepresentasikannya yang dapat digunakan untuk memahami dinamika relasi romantis di masyarakat Bali saat ini. Dua fase penelitian dilakukan melalui survei dan FGD. Respondennya adalah remaja suku Bali yang berusia 15-17 tahun $(n=277)$. Melalui prosedur analisis tematik, beberapa tema yang muncul diidentifikasi sebagai konseptualisasi relasi romantis. Relasi ini dikonsepkan sebagai suatu hubungan yang eksklusif, dan mencakup dimensi afektif, kognitif, dan psikomotor, dan diwakili dengan sejumlah istilah. Kesimpulan yang bisa diambil adalah bahwa konsep relasi romantis dapat dipersepsikan secara berbeda bagi setiap individu dari budaya yang sama sehingga akan menyebabkan bentuk-bentuk perilaku remaja yang juga bervariasi.
\end{abstract}

Kata kunci: konsep, persepsi, relasi romantis, remaja, suku Bali 


\section{Introduction}

Romantic experience is an important source of socialization for adolescents and reflects their need for developing connections outside of the family as intimacy with peers and romantic partners increases while that with parents decreases (Collins, 2003). Romantic experience includes varied behavioral, cognitive, and emotional phenomena with romantic content, such as fantasies, infatuations, conversations with friends about romance and potential partners, and relationships of short and long duration (Collins, Furman, \& Welsh, 2009). The romantic relationship is a fundamental social psychological phenomenon (Cavanagh, 2007). Romantic relationships are a central aspect of an adolescent's life and have an important influence on the development of social and sexual affections. Romantic relationships are believed to play an important role in identity formation, the transformation of family relationships, the development of close relation with peers, and school achievement and career planning (Furman \& Shaffer, 2003).

One of the limitations of research in this field is the difficulty of providing unique and standards definitions of romantic relationships due to cultural differences in conceptions and the differences within individuals from the same cultural group. Conceptualizations of adolescent romantic relationships have been remarkably consistent across existing studies, yet no standard operational definitions exist or have been well specified in the broader domain of romantic experiences. Researchers typically have asked participants if they have a romantic relationship (or a boyfriend or girlfriend), and the participants decide it based on their own definition. A brief description is sometimes provided for clarification (e.g., "when you like a guy [girl], and he [she] likes you back") (Giordano, Manning, \& Longmore, 2005).

Karney, Beckett, Collins, and Shaw (2007) also reported the lack of precise terms as the main obstacle for the study of romantic relationships. They stated that researchers tend to leave the task of definition to the study participants by deciding whether and when they are in romantic relationships. In her literature review, Jackson (1999) also expressed concern about the failure of defining what is meant by dating and proposed that confusion about dating could be avoided if researchers would make explicit their operational definition of dating for any given study. Unfortunately, most researchers do not pay sufficient attention to this issue even today. Romantic relationships are being redefined while cultural expectations and social values shift (Kuperberg \& Padgett, 2016). This problem is the basis of this research, which seeks to explore the concept of romantic relations in a society of a particular culture.

Conceptualizing romantic relationships that belong to a group of individuals, such as adolescents, would help us obtain a comprehensive understanding of adolescent attitudes and behavior in this relationship. Knowing how adolescents perceived romantic relationship could be predicted by the possibility of the emergence of deviating behavior. That is not according to norms and values in a society that can harm her/his self and others and maybe the emergence of attitude and behavior that is more beneficial for their development as individuals. For example, when sexual behavior appears as part of adolescents' understanding of what to do in a romantic relationship, this gives information to us that sexual behavior is very likely to be carried out by adolescents when they begin to have relationships with the opposite sex. The romantic relationship might shift from group interaction to one-on-one encounters focused on emotional connections and potential involvement in sexual behaviors (Whittecar, 2019). Manning, Longmore, and 
Giordano (2000) stated that a romantic relationship is a typical context in which adolescent sexual behavior appears. Boislard, van de Bongardt, and Blais (2016) reviewed numbers of studies and revealed that adolescents generally begin to actively engage in sexual behavior in the context of romantic relationships. Romantic relationships are also considered as a normative prerequisite for sexual intercourse for the first time. This suggests that romantic activity and sexual activity tend to go hand in hand. This is also in line with the study of Royer, Keller, and Heidrich (2009), which revealed that adolescent descriptions of romantic relationships show forms of sexual behavior carried out by adolescents. In addition, some studies indicated that sexual behavior that occurs in adolescents during this relationship increases the risk of mental health problems. Adolescents who have had sexual intercourse with the romantic partner showed higher symptoms of depression than those who have never done it (Soller Haynie, \& Kuhlemier, 2016), besides the risk of unwanted pregnancy, sexually transmitted diseases, and HIV (Boislard et al., 2016).

A study conducted by Barton, Hurt, Futris, Sheats, McElroy, and Landor (2017) on African American adolescents focused on perceived commitment as an important part of romantic relationship conceptualization. By exploring this concept, the researchers understood the lower rate of marriage and marital stability levels in African American people compared with other ethnicities. However, commitment is not an issue that exclusively affects adults, but it emerges prominently during the developmental stage of adolescence, when romantic relationships are typically initiated. The findings showed that commitment in romantic relationships includes feeling supported, cared for, or invested in by their partner. Adolescents also describe commitment as a lack of pursuing other romantic relationships, remaining honest and monogamous. In addition, affection and intimacy, interdependence, and sexual interaction were also needed in a romantic relationship.

The importance of understanding the concept of romantic relationships from the perceptions of adolescents also can be the basis for designing a prevention program against teen dating violence as conducted by researchers from the U.S. Department of Justice (2014). This study identified a number of themes on conceptualizing romantic relationships based on adolescents' experiences, namely, positive communication and connection, early stage of a relationship, signs of commitment, social concerns and consequences, insecurities, intense focus on the relationship, warning signs, and dependency. Positive communication and connection deals with how adolescents describe an ideal romantic relationship's characteristics related to relationship satisfaction. Early stage of a relationship, insecurities, and intense focus on the relationships relate to new experiences in terms of romantic relationships for adolescents. Aspects in these themes include the attachment and development of adolescents who begin to switch from relationships with family to peers during their first experiences with romantic partners. The sign of commitment is related to the existence of a more serious relationship and the existence of efforts to build a relationship. Social concerns and consequences relate to the context of development and the perspective of attachment, including the experiences of adolescents with peers as models and influences. Warning signs, dependency, and abuse are themes that cover aspects of unhealthy and abusive experiences in adolescent romantic relationships. This study's results are useful to design a preventive program for teen dating violence in the U.S.

According to Collins (2003) and Collins et al. (2009), romantic relationships are mutually recognized voluntary interactions, which have different intensities, generally 
characterized by expressions of affection and the possibility of current or anticipated sexual behavior, when compared to other peer relationships. Brown, Feiring, and Furman (1999) propose that romantic relationships are voluntary dyadic relationships acknowledged by two individuals characterized by affiliation, intimacy, companionship, and for most, a sexual component. These definitions have often been used in studies of romantic relations to understand the forms of relations that lead to behaviors that can be categorized as romantic.

The development of a romantic relationship is also influenced by cultural context related to the age when adolescents engage in romantic activities, the perceptions about sexual behaviors, and how they respond to the emergent conflict (Connolly \& McDonald, 2020). Every culture forms a certain background in which romantic relationships emerge. Culture gives influences to the way individuals perceive a romantic relationship. Individuals from different cultures are very likely to have different perceptions of romantic relationships, depending on experience and values in society. In this case, the concept of romantic relations is viewed from an ecological perspective, which emphasizes the social and cultural context in looking at these relationships. According to the ecological approach, a romantic relationship develops with the background of certain values, norms, and expectations (Collins et al., 2009)

In a collective culture, individuals are encouraged to consider love and romantic relationships in a larger context of family and community obligations (Blair \& Madigan, 2016). In this cultural view, parents can be a major socializing force for adolescent romance, and the transmission of cultural knowledge about a romantic relationship can emphasize respect for the family of origin, the importance of responsibility, and the function of having children (Seiffge-Krenke, 2010). In an individualistic culture, individuals value the freedom to live romantic relationships that can satisfy their own personal development without interference from parents, and friends play an important socialization role in this process (Seiffe-Krenke, 2010). On the other hand, when adolescents, who come from societies with collectivist cultural view, have received influences from Western culture that tends to be individualistic, then there is a shift in their attitude and behavior, such as in romantic relationships. Relationships in India society had historically been rooted in fixed social networks that were delimited by kinship boundaries. Adolescent socialization is directed at developing filial piety rather than personal autonomy. A recent study of India adolescents tends to show that those in increasingly Westernized contexts reported more romantic activities and have greater autonomy from parents in partner selection, as well as the influence of Western media consumption, greater cross-sex network composition, and intimate communication (Dhariwal \& Connoly, 2013).

Romantic relations are fundamental social psychological phenomena (Cavanagh, 2007). While individual feelings about romantic activity originate from their personal values, they also reflect ideological beliefs that are widely adopted by society and culture (Cavanagh, 2007), including the structural, cultural, and closest contexts we live in (Hochschild, 1979; Cavanagh, 2007). This contextual ideological belief guides thoughts and actions, shapes emotional experience, and influences romantic expectations (Cavanagh, 2007), and helps identify appropriate objects of these feelings and behaviors (Hochschild, 1979; Simons et al., 1992), and provides a lens for individuals to interpret and react to events related to romantic experiences (Sarantakos, 2005). Because understanding and experience of romantic relationships tend to be products of existing 
cultural meaning systems (Collins \& Madsen, 2006), they reflect representations of socially constructed reality.

The Balinese people grow in a thick order of cultural values and traditions that are hereditary. Balinese culture's salient characteristic is that it is closely related to religious values. For the Balinese, culture is a framework with Hindu religion's aim. The culture was created not only to achieve the goodness of life in the world (Jagadhita), but the most important is to become one with God. That is why the form of culture is expressed in religious concepts or frameworks, which means that whatever is created in the cultural creations of Balinese people is never separated from the framework of Igama (Tatwa/the essence of truth), Agama (morality, ethics) and Ugama (Yadnya/rituals). This concept regulates the Balinese way of life (Dharmayuda, 1995). Widhiyanti Yuniarti, Minza, and Riyono (2019) identified the values that are considered important as references in the romantic relationship of Balinese adolescents' perceptions within the framework of type of value theory proposed bay Schwartz. The themes that emerged are related to the type of value of tradition, security, conformity, benevolence, and universalism. These values are reflected in a number of Balinese philosophies and Hindu religion. These values are believed to guide individuals when interacting with opposite sex, engaging in romantic relationships, and choosing a romantic partner. On the other hand, a small proportion of Balinese adolescent respondents did not consider these values important when establishing romantic relationships, so the value type related to openness to change seems to be dominating for these individuals.

Changes in all aspects of life, which are mainly caused by the development of tourism and technological advances, also occur in Balinese society from generation to generation. Today's Balinese adolescents who grow and develop with all modernization show changes in attitudes and behavior, in this case related to romantic relationship. In general, the use of technology has changed human interaction by blurring the boundaries and rules of interacting with one another, primarily changing the process for initiating, maintaining, and terminating an intimate relationship (Hertlein 2012). The impact of modernization on adolescents occurs through the influence of information technology and mass media development, which provides entertainment, information, modeling, coping, and youth culture identification (Panahi, 2015). Findings from Vaterlaus, Tulane, Porter, and Beckert (2017) were also clearing that entertainment media provided media role models for expected behavior in romantic relationships and related to the development of unrealistic relationship expectations and perceived pressure be in a romantic relationship.

As previously stated, Balinese adolescents as part of the global community inevitably interact with other cultures and are in touch with advances in information technology with all the consequences. One of the phenomena that underlie this research's urgency is Balinese adolescents sexual behavior in the context of romantic relationships. Survey on adolescents in Denpasar conducted by KISARA (Kita Sayang Remaja) from the youth program of the Perkumpulan Keluarga Berencana Indonesia (PKBI) Bali, in 2016. The result showed that out of 1200 respondent aged $11-15$ years old, $73.33 \%$ had engaged in romantic relationship (dating), as many as 57 teenage couples were actively having sexual intercourse, $16.6 \%$ of respondents thought that vaginal sex can be done before marriage, and $18.7 \%$ of respondents reported that petting and oral sex could be done before marriage, and $48.9 \%$ thought that kissing and hugging are common activities on dating (Eurazmi, 2018). Kartika and Budisetyani (2018) found that out of 65 Balinese adolescents in Denpasar and Badung Regency, 64.5\% had had premarital sexual intercourse with their romantic partner. The phenomenon of premarital sexual behavior 
was also found in senior high school students in Buleleng Regency, out of 566 adolescents, $13.1 \%$ had already had sexual intercourse with their partner (Wijaya, Giri, Wahyuni, \& Setiawan, 2018).

Those phenomena of risky behavior occur in the context of romantic relationships, raising questions about how Balinese adolescents perceive these relationships. By exploring the concept of romantic relationships held by Balinese adolescents, it is hoped that it can be a meaningful beginning to understand the dynamics of Balinese adolescents' attitudes and behaviors in a romantic relationship. So the urgency of this study is as a basis to predict Balinese adolescents' attitude and behavior related to romantic relationships, and hopefully, the findings of this study can contribute to the formulation of policies related to youth education, especially in Bali.

According to the problem, the objectives of this study are to explore the concept of a romantic relationship from the perceptions of Balinese adolescents and to identify terms that represent this kind of relationship that can be used to comprehend the dynamics of romantic relations in Balinese culture. The concept of romantic relationships produced will be discussed in the context of the characteristics of relationships that characterize cultural views and differ from other forms of relations in adolescents' lives, such as friendship relations and relationships with parents.

\section{Methods}

\section{Participants}

This study used the exploratory qualitative approach. An exploratory approach is used when there is little or no previous research that can be referenced or relied upon to predict the study's outcome. This approach's focus is to gain insight into a topic that will be explored further or carried out as part of the initial investigation. They are also often used to build an understanding of how best to learn more about a topic and are useful for determining what methods can be used to effectively gather information about the problem (Kabir, 2016). In this case, the concept of romantic relations from Balinese adolescents' perspective has never been studied in previous studies so that an exploratory approach can be used as an initial method before carrying out more in-depth studies of romantic relationships in Balinese society.

Before carrying out the survey, researchers processed several procedures such as obtaining ethical clearance from the ethics team of the Faculty of Psychology, Gadjah Mada University, research permits to secondary schools in Buleleng, Denpasar, and Badung, Bali, and conducting discussions with experts regarding the content of the questionnaire to be used. Informed consent was made by explaining the researchers' identity, research objectives, and important points that can be used as considerations for respondents to accept or refuse to be involved in the research. The consideration of choosing these schools areas to be involved was based on the evidence from the studies' results that showed the phenomenon of sexual behavior in the context of romantic relationships of adolescents (Wijaya et al., 2018; Kartika \& Budisetyani, 2018).

The survey was conducted offline by directly visiting schools that involved its students in this study. Not all schools responded immediately to the research permit application letter within the specified research timeframe. In this condition, only two schools in Badung Regency and two schools from Badung Regency were the most available to be involved in this study. The data was collected through 2 phases. In the first 
phase, data were collected using a survey through the distribution of open-ended questionnaires. At the second phase, two sessions of Focused Group Discussion (FGD) were held. There were two stages of data collection in this study, the first was distributing questionnaires to students, and the next stage was the implementation of two sessions of FGD. The students involved in the FGD voluntarily joined the forum to share their experiences and perceptions. The first FGD was conducted involving students in Buleleng Regency and the second was conducted by involving students in Badung Regency. Data collections and FGD were carried out from April to May 2019. The participants were adolescents aged 14-17 years old $(n=260)$ on the first phase and adolescents aged 15-17 years old $(n=17)$ on FGD. Participants were students from junior and senior high schools in Badung and Buleleng Regency, Bali. The sampling technique used in this study was purposive sampling that involved adolescents as the age group that is most closely related to the experience of romantic relationships and they are at a time when romantic relationships are an important part of their development.

\section{Measurement}

In qualitative research, most questions are open-ended in nature. Open-ended questions offer respondents an opportunity to provide a wide range of answers and to express an opinion without being influenced by the researcher (Hyman \& Sierra, 2016; Reja, Manfreda, Hlebec, \& Vehovar, 2003). The questionnaire consists of two questions: the definition of a romantic relationship according to adolescents' perceptions and identified terms used in their daily lives that can represent the form of this relationship.

The FGD was conducted after the survey data analysis process reached the final stage in determining themes. The FGD was conducted as the confirmatory process of the survey results. FGD was started by sharing perceptions regarding the romantic relationship, experiences that could be categorized as romantic relationships, and the emotional, cognitive, and behavioral aspects that were considered to be involved in the relationship and describing romantic relationships in some terms that popular among them. A Focus Group Discussion (FGD) is a qualitative research method and data collection technique in which a selected group of people discusses a given topic or issue in-depth, facilitated by a professional, external moderator. This method serves to solicit participants' attitudes and perceptions, knowledge and experiences, and practices shared in the course of interaction with different people (van Eeuwijk \& Zuzanna, 2017). The first session of FGD conducted in Buleleng Regency, involving 5 students from a private high school and 5 students from a public high school; the second session was conducted in Badung regency, involving 7 students from a public high school.

\section{Analysis}

Data is analyzed through thematic analysis to formulate the concept of romantic relationships based on perceptions and experiences of Balinese adolescents. Thematic analysis is the process of identifying themes within qualitative data, i.e. patterns in the data that are important or interesting, and use these themes to address the research or say something about an issue (Maguire \& Delahunt, 2017). Braun and Clark (2006) provide a six-phase guide to do the thematic analysis. These steps are (1) becoming familiar with the data, i.e. involving reading and re-reading the entire body of data before go any further; (2) generate initial coding, i.e. start to organize data in a meaningful and systematic way; (3) search for themes, i.e. find a pattern that captures something significant or interesting about the data; (4) review the themes, i.e. modify and develop 
the preliminary themes that identified in step 3; (5) define themes, i.e. the final refinement of the themes and the aim is to identify the essence of what each theme is about; and (6) write-up.

The respondents' data is in the form of descriptions of what is meant by romantic relationships based on respondents' perceptions and data about terms commonly used to represent this form of relationship in adolescent daily life, including the characteristics that distinguish each of these terms. The researcher reads the description set and begins the coding process to bring up themes from the existing data. In this first stage of coding the researcher compiles an initial list of interesting things in the data and refers to the most basic segment, or element, of the raw data or information that can be assessed in a meaningful way regarding the phenomenon. In this phase, the researcher can bring up as many as potential themes/patterns as possible.

The next stage, when the researcher has a list of codes that are different from the data, the analysis process focuses on a broader level of themes, sorting the different codes into potential themes, and collating all the relevant coded data extracts within the identified themes. Researchers began to think about the relationship between codes and themes. Some of the initial codes can be the main themes, and others can be the subthemes. After this phase, the researcher begins to refine the existing themes by reviewing whether these themes can be combined, some can be broken down, or there are themes that are not supported by data or are too diverse. Then in the next phase, the researcher refines the theme by identifying each theme's essence and determining what aspects of the data each theme captures. These themes are structured coherently and consistently with the accompanying narrative. In the end, the researcher wrote a report that provided a precise, coherent, logical, and interesting explanation of the story in the data (Braun \& Clark, 2006). The data obtained from Focus Group Discussion (FGD) was the data needed to confirm the themes that emerged from the survey to deepen researchers' understanding of adolescents' way of thinking about romantic relationships without neglecting the possibilities of new themes emerging. As far as what was found, the survey and FGD showed a parallel understanding of the concept of romantic relationship among adolescents.

\section{Findings}

The findings showed that the concept of romantic relations according to Balinese adolescents characterize as exclusive relationship, and contain elements of affective, cognitive, and psychomotor, which arise from adolescents' experiences, and some terms represent the relationship. Romantic relations are interpreted as a relationship that has certain characteristics so that it can be said to be different from other forms of relations. The characteristics that emerge are presented below.

Table 1. Sample of response based on emergent themes

\begin{tabular}{lll}
\hline Emergent Themes & Descriptions & Sample of response \\
\hline Exclusive relationship & $\begin{array}{l}\text { Is special, reciprocal, and "relationship that is based on love for } \\
\text { voluntary relationships }\end{array}$ & $\begin{array}{l}\text { each other without any coercion } \\
\text { because they feel belong to each } \\
\text { other" }\end{array}$ \\
& $\begin{array}{l}\text { Done consciously, with mutual "relationship that intertwines } \\
\text { commitment and expectations. }\end{array}$ & $\begin{array}{l}\text { consciously that based on compassion } \\
\end{array}$
\end{tabular}




\begin{tabular}{|c|c|c|}
\hline Emergent Themes & Descriptions & Sample of response \\
\hline & \multirow{4}{*}{$\begin{array}{l}\text { Different from friendship in terms } \\
\text { of closeness, depth of feelings, } \\
\text { consideration about partner's } \\
\text { characteristics, communication } \\
\text { intensity, type of joint activities, } \\
\text { and physical contact. }\end{array}$} & $\begin{array}{l}\text { and there is an agreement to take care } \\
\text { and protect each other" }\end{array}$ \\
\hline & & $\begin{array}{l}\text { "it's an expression of feelings that are } \\
\text { special to one person that we consider } \\
\text { more than just a friend and feel the } \\
\text { same way to us" } \\
\text { "...that we can put hope in this } \\
\text { relation that we will be together with } \\
\text { the person we like to give the best for } \\
\text { each other" }\end{array}$ \\
\hline & & $\begin{array}{l}\text { "relationship with the opposite sex } \\
\text { that more than just a friend because it } \\
\text { involves the feeling of love and fear of } \\
\text { losing someone." }\end{array}$ \\
\hline & & $\begin{array}{l}\text { "...can do activities that are generally } \\
\text { done by men and women who like each } \\
\text { other, such as watching movies, or } \\
\text { maybe kissing, hugging" }\end{array}$ \\
\hline \multirow[t]{7}{*}{ Affective dimension } & $\begin{array}{l}\text { Positive and negative emotions } \\
\text { are more intense and complicated, } \\
\text { such as love, admiration, } \\
\text { possessiveness sincerity fear of }\end{array}$ & $\begin{array}{l}\text { "relationship that involves affection, } \\
\text { possessiveness, make us comfortable, } \\
\text { and sometimes make us jealous." }\end{array}$ \\
\hline & $\begin{array}{l}\text { loss, unselfishness, sadness, } \\
\text { anger, and jealousy. }\end{array}$ & $\begin{array}{l}\text { "relationship that is based on sincerity } \\
\text { to do what's best for your partner } \\
\text { because of fear of losing and } \\
\text { sometimes you need to scarify too" }\end{array}$ \\
\hline & \multirow{5}{*}{$\begin{array}{l}\text { Romantic relationship as a } \\
\text { purposeful and impactful form of } \\
\text { relation that gives positive and } \\
\text { negative experiences to } \\
\text { adolescents. These experiences } \\
\text { include starting to know about the } \\
\text { characteristics of the opposite } \\
\text { sex, affecting academic } \\
\text { motivation, and considering } \\
\text { harming individuals when they } \\
\text { act against the norms. }\end{array}$} & $\begin{array}{l}\text { "relationship that makes us recognize } \\
\text { what jealousy is and it become } \\
\text { difficult to concentrate on thinking } \\
\text { about the person we like so much." }\end{array}$ \\
\hline & & $\begin{array}{l}\text { "...he can make us more motivated to } \\
\text { show our achievement, this } \\
\text { relationship can be beneficial too" }\end{array}$ \\
\hline & & $\begin{array}{l}\text { "relationship that get us into a more } \\
\text { serious future relationship with people } \\
\text { we want." }\end{array}$ \\
\hline & & $\begin{array}{l}\text { "relationship that makes us more } \\
\text { mature and thinks seriously to } \\
\text { determine the course of life." }\end{array}$ \\
\hline & & $\begin{array}{l}\text { "...sometime lead us to behave } \\
\text { violating norms if we just lose control }\end{array}$ \\
\hline \multirow[t]{2}{*}{ Psychomotor dimension } & $\begin{array}{l}\text { Related to the content of relation, } \\
\text { such as the joint activities with a } \\
\text { romantic partner, ranging from } \\
\text { hanging out to sexual activities. }\end{array}$ & $\begin{array}{l}\text { "...to have a partner to accompany } \\
\text { you to do entertaining activities } \\
\text { together." }\end{array}$ \\
\hline & & $\begin{array}{l}\text { "...involves hugging and kissing with } \\
\text { your loved one to express you } \\
\text { feelings." }\end{array}$ \\
\hline
\end{tabular}




\begin{tabular}{|c|c|c|}
\hline Emergent Themes & Descriptions & Sample of response \\
\hline & & $\begin{array}{l}\text { "...it could be involved consensual } \\
\text { sexual behavior with the partner." }\end{array}$ \\
\hline \multirow{5}{*}{$\begin{array}{l}\text { Terms represent the } \\
\text { romantic relationship }\end{array}$} & Terms represent romantic & \multirow{4}{*}{$\begin{array}{l}\text { "usually known as pacaran or jadian" } \\
\text { "known as pacaran and there is } \\
\text { already a commitment, it also known } \\
\text { as PDKT (pendekatan) with someone } \\
\text { we like." } \\
\text { "it can be termed makabakan or } \\
\text { matunangan in Balinese language, it } \\
\text { is just the same as pacaran" }\end{array}$} \\
\hline & relationships with various & \\
\hline & $\begin{array}{l}\text { languages, such as Bahasa, } \\
\text { English, and Bahasa Bali, } \\
\text { including a metaphor. }\end{array}$ & \\
\hline & $\begin{array}{l}\text { Terms in Bahasa: Pacaran, } \\
\text { Teman Tapi Mesra (TTM), } \\
\text { PDKT (pendekatan), jadian, doi, } \\
\text { cemewew, gebetan, kencan, } \\
\text { Teman Rasa Istri (TRI) }\end{array}$ & \\
\hline & $\begin{array}{l}\text { Terms in English: Friendzone, } \\
\text { backstreet, taken, Friend With } \\
\text { Benefit (FWB), relationship, }\end{array}$ & \\
\hline
\end{tabular}

\section{Exclusive relationship}

Through thematic analysis procedures, it can be formulated that romantic relationship is a special and reciprocal relation that has a mutually agreed commitment and is carried out consciously and voluntarily between two people of the opposite sex (male and female). This relationship is a bond that is deeper than just a friend, does not involve other people outside the spouse, and is unique to each couple. This relationship shows the importance of the couple's acceptance, understanding, and compatibility when starting the commitment. Both individuals also have certain expectations about what they want to get from the relationship. This romantic relationship involves two people of opposite sex, namely men and women. The concept of heterosexuals is still a reference for adolescents in their sexual orientation. Adolescents reveal that their culture does not accept homosexual romantic relationships and it is normal for relations to be made between people of different sexes.

The above findings appear to be confirmed through the FGD. Romantic relationships are relationships that require commitments that are directly expressed by couples, such as agreements on boundaries about things that may or may not be done by individuals, such as limiting interactions with other girl/boy. Romantic relationships are also initiated and done on the adolescents themselves' wishes. They live it as a couple without coercion such as arranged relation, and there is no interference from other people, such as friends. Friends are seen as being able to inhibit a relationship if a friend dominates an individual's behavior when interacting with the opposite sex and expresses disapproval of his/her choices. On the other hand, parents' role is considered still important, especially in terms of parental trust that adolescents will have positive romantic relationships.

Adolescents argue that romantic relations are quite different from other forms of relations, in this case is friendship, although it does not mean the possibility that this romantic relationship begins with friendship. A number of differences are expressed related to the level of closeness, depth of feeling, consideration of characteristics, the intensity of communication, type of activity, and physical contact. A more intimate level of closeness characterizes romantic relationships, and romantic partners are more prioritized than friends. Romantic relations have a purpose for the future, especially with regard to life partners, but in friendship this is not so important because friendship can 
change over time and there is no exclusivity in relationship which means that relationships can be done with anyone and with many people at one time.

Feelings that are involves in romantic relationships are reported to be more profound than in friendship. Romantic relationships are based on feelings of love that are not felt in friends, just as the emergence of jealousy is only experienced in romantic relationships. Friendship does not cause the appearance of jealousy and less risk of causing heartbreak. In romantic relationships, there is a sense of possessiveness and fear of loss, feeling of longing, and demand special attention in conflict. If a conflict arises in friendship, it is considered easier to resolve because it is not based on deeper feelings with the risk of more severe heartbreak. Friendships tend to be more relaxed and not too draining.

Finding suitable friends to interact in daily activities is considered sufficient in friendship. But it is different in the context of romantic relations. Romantic partner selection takes into account more comprehensive characteristics. Interaction and communication with romantic partners have a higher intensity than friendship relations. Interaction with friends is often limited to school or extracurricular activities that are jointly followed, but for adolescents who have established romantic relationships more intensive interactions are carried out with higher frequency, as long as the opportunity and time they have. Romantic couples have special ways to express their feelings, but not in friendship. Physical contact such as hugs and kisses is part of a romantic relationship and this does not occur in friendship relations. Activities with romantic partners are related to spending time together to get to know each other. Activities with friends can also be a place for romantic couples to meet and do activities together.

From this understanding of romantic relationships, it also found three dimensional groups that are included in the concept of romantic relationships perceived by adolescents. These three dimensions are seen as important aspects so that the relationship can be viewed as a romantic relationship.

\section{Affective dimensions}

The dimensions of affection are related to the forms of feelings involved in interactions that they consider to be romantic relationships. These kinds of feeling are affection, love, interest, admiration, possessiveness, fear of loss, sincerity, unselfishness, willingness to protect the loved one, and sometimes occur beyond common sense.

From FGD it was found that feelings of love, interest, and admiration have become the beginning of this special relationship's formation. Feelings of love and love grow out of interest-based on a partner's certain characteristics, both physically, personality, and competence. All the feelings that emerged in this romantic relationship are based on sincerity.

Feelings that arise along with the passage of this romantic relationship are the fear of losing, longing for not meeting, comforting and calming, respecting, and meeting the needs of companionship. On the other hand, negative emotions can also emerge in this relationship in the context of conflict. Feelings of sadness, anger, and jealousy arise because they feel ignored. Positive and negative emotions emerge in this kind of relationships are generally more intense and complicated than in other relationships in adolescents' lives. 


\section{Cognitive dimensions}

According to adolescents' perception, this romantic relationship is purposeful and impactful. Romantic relationships have a purpose for preparing future plans related to married life and as a process of recognizing the characteristics of the opposite sex. Adolescents also perceive that romantic relationships are part of an important and reasonable adolescent development phase that can affect adolescent development, both positively and vice versa. Positive impacts revealed such as encouraging personality formation through interaction with the opposite sex, creating a feeling of comfort, increasing academic motivation, and becoming a way to unite differences with partners. Negative impacts refer to risky behavior that could harm oneself and family.

The FGD participants argued similarly, they mentioned that romantic relations have more specific goals than friendship, that is, as an initial stage to find a partner through a more personal process of introducing the opposite sex. In this relationship, adolescents also get more attention from the partner they like. This relationship is perceived as useful for maturing oneself, is a process to get to know oneself better and become a better individual. The partner learns to understand the occurrence of conflict in a relationship and the reason for the emergence of negative and positive feelings in the relationship or learn to understand the reasons behind an action taken by a partner. Increased academic motivation is also influenced by the formation of romantic relations with the existence of mutual support in the learning process.

The negative impact that is considered to arise in the context of the relationship with the opposite sex is when the behavior is against society's rules so that it can harm individuals. Adolescents perceive that romantic relationships are a form of relationship that must be taken seriously. The example is that adolescents should not easily change partners to avoid society's bad impressions.

\section{Psychomotor dimensions}

Psychomotor dimensions that arise from survey results include forms of behavior and activities carried out in the context of a romantic relationship, such as (1) disclosure of feelings, (2) protective behavior, attentive, supportive, caring, and sacrifice, (3) activities carried out together with couples, from hang out to sexual intercourse. Whereas from the FGD results, participants revealed similar themes to the data previously obtained. In a romantic relationship, both individuals must express their feelings in the form of reciprocal actions, showing more closeness and behavior that is bound to one another. As mentioned earlier, romantic relationships are characterized by physical contact, such as hugging and kissing, and the existence of activities, both recreational and academic, which are carried out together with a partner.

Adolescents also perceive that in a romantic relationship, couples need to show attitudes that aim to support the relationship's continuity. Attitudes that are considered important, namely mutual care, mutual understanding of each other's conditions, can be mutually dependable, protect, support, help, encouraging, listening, loyal, trying to be better person, be the person who knows best about each other's conditions, and keeps promises. A series of attitudes are important in a relationship and it is the duty of the couple to do it so that the relationship can last long.

\section{Represented by popular terms}

Adolescents identify several terms that they use in everyday life to represent romantic relationships, such as "berpacaran"; Teman Tapi Mesra (TTM); PDKT 
(pendekatan); Friendzone, matunangan, makabakan (in Balinese); backstreet, taken, jadian, gebetan, kencan, metaphor such as "a pair of shoes that always together", mecekle, cemewew, doi, relationship, couple goals, TRI (teman rasa istri), FWB (friend with benefit).

Through the FGD, several terms representing romantic relationships among Balinese teenagers were also mentioned. The most commonly used term is "pacaran" (dating). The FGD participants then confirmed with further explanation of the terms obtained from distributing the questionnaire.

"Pacaran" (dating) is the most commonly used term to describe the existence of a special relationship between unmarried men and women, marked by "jadian", and calling each other together with the terms "pacar" (girlfriend/boyfriend), "doi", and "cemewew". The term "gebetan" is closer to meaning as someone who is liked and targeted to be a romantic partner. The process of approaching and attracting the attention of the opposite sex is preferred or can be the initial introduction period before committing is called the term PDKT ("pendekatan"/approaching). "Kencan" is a term that describes activities in dating, the form such as walking together, watching movie, and dinner with a partner.

If two people like each other and are still friends, then the term is Teman Tapi Mesra (TTM), and if someone likes his/her own best friend then it is called Friendzone. While the term TRI (Teman Rasa Istri) represents a very close and intimate partner relationship.

Some terms in the Balinese language, which means dating are "matunangan" or "makabakan", the mention of a partner with the term "tunangan" or "kabak". Another term in the Balinese language that is revealed is "mecekle", which means having sexual relations with a partner.

A number of terms are taken from English, such as Friendzone, backstreet, taken, relationship, couple goals, and Friend with benefit (FWB). Backstreet represents a condition in which couples establish romantic relationships clandestinely, it is not known by parents, or even friends. Taken is a term that means someone has become someone else's partner. Teenagers also use the term "relationship" to represent dating terms, while the couple goals term is used to describe a harmonious romantic partner. The term Friend with benefit (FWB) is a term that represents the status of the relationship between the two individuals with no commitment to be a couple, but it involves physical contacts including sexual actions.

The use of metaphor to represent romantic relationships also arises from Balinese teenagers' opinions, who describe it as a pair of shoes that are always together. This illustrates two individuals who are inseparable and become incomplete or lost if one is not present.

\section{Discussion}

Balinese adolescents participated on this study have varied opinions about romantic relations according to their perceptions and experiences. The results described above categorize the emerged themes, which are assumed to be the characteristics that must exist in a romantic relationship. Romantic relationship is described as a form of an exclusive relationship, it means that there is an agreement made by the couple committed in all matters related to the romantic relationship they intertwine. Adolescents also proposed that romantic relationships require feelings, attitudes, and actions that are reciprocal, such as mutual acceptance and mutual understanding. 
Furman and Shoemaker (2008) proposed that romantic relationships primarily differ from friendships in terms of their passionate aspects, including a fascination with the other, sexual desire, and exclusiveness of the relationship. Balinese adolescents revealed that romantic relationships have some different characteristics compared to friendship, in terms of closeness, depth of feeling, consideration of the personality, intensity of communication and types of joint activities. Romantic relationships generally involve more intimate feelings and activities compared to friendships. Every romantic couple lives their relationship in a unique way, different from other partners. The concept of romantic relations in Balinese adolescents' perceptions shows that closeness is woven consciously and voluntarily based on a match, without any coercion from outside parties. This confirms that romantic relations between two individuals do not involve other people in the relationship.

In terms of relational commitment issues, collectivists, structural commitment in an intimate relationship may be more important than (or at least on an equal footing with) personal commitment in a long-term romantic relationship. Structural commitment means that the individual takes into consideration various external social and family reactions in deciding either to continue or to terminate a relationship (Ting-Toomey, \& Dorjee, 2019). Individualists tend to expect voluntary personal commitment from their partners in approaching their intimate relationships. However, personal commitment, on the one hand, means an individuals' desire or intent to continue the relationship based in his or her subjective emotional feelings and experiences. The emphasis on voluntary attitudes without coercion in a romantic relationship, as perceived by Balinese adolescents, at a glance shows that adolescents refer to personal commitment and not structural commitment. Adolescents do not explicitly show the importance of external considerations in deciding whether or not a relationship is made. Although there are also some opinions about the need to inform parents about the relationships so that they could get trust from their parents. Generally, on this study, Balinese adolescents perceived that a romantic relationship is a personal decision that does not require parents' interference because it involves feeling and desire that cannot be determined by others. This matter indicates the tendency of autonomy in adolescents as part of their development.

The achievement of personal autonomy as the ability to set life goals, implement a personal, free choice, and gain self-confidence is a key of adolescence. The relation between parent and child reveals the opportunities for the balance of individuation and cooperation with parents to develop personal autonomy. Adolescents included in warm emotional relationships with parents, receiving care and support tend to independent decision making and self-expression, show more psychological maturity, and feel more confident (Karabanova, \& Poskrebysheva, 2013). This discussion is still needs to be confirmed by future exploration to describe about adolescents' views regarding their parents' role in the romantic relationship.

Romantic relations can be done between individuals with different sexes (heterosexual) and the same (homosexual). Ethnographies of different social and cultural groups consistently suggest that heterosexuality is not the only form of sexual behavior and multiple reports suggest that sexual orientation goes beyond what people find attractive (Blackwood, 2010; Tskhay, \& Rule, 2014). There are notable works describing aspects of sexual orientation that are more closely related to cultural practices, traditions, and institutions than to sexual relationships alone. For Balinese adolescents, the concept of romantic relations is intertwined between male and female, and there was no response to the romantic relationship between the same sexes. Adolescent perceptions are 
influenced by Balinese culture views that prefer heterosexual than homosexual relationships. In addition, these findings indicate the experience of Balinese adolescents in the present who still have a sexual orientation to the opposite sex. While in friendship, the interaction could be done both with the opposite sex and with same-sex friends.

Collins (2003) proposes five dimensions in romantic relationships, namely romantic involvement, partner selection, relationship content, quality of romantic relationships, and cognitive and emotional processes. The emotional process dimensions presented by Collins (2003) include the moods elicited in the relationship, as well as the use of romantic relationships to process (or avoid) emotions elicited by other aspects of one's life. The cognitive dimensions include perceptions, attributions, and representations of individuals, couples, and relationship. This study's findings show that couples' feelings are the most important part of romantic relationships. The romantic relationship concept is always associated with positive feelings towards someone, which begins with interest. In the other hand, at the process of the relationship itself, the risk of negative emotions can occur during a conflict. Emotions are the core elements in the functioning of intimate relationships. Positive emotions predict the initiation of predictive dissolution of relationships and negative emotions (Laurenceau et al., 2005). Romantic relationships represent the primary context for both the experience and emotion expression.

Positive feelings or negative feelings in romantic relationships are expressed in the form of behaviors aimed at harmonizing relationships. This is also inseparable from the cognitive dimension that plays a role in perceiving the relationship's goals and impacts or benefits and attributing to the partner's behavior. Balinese teenagers perceive that romantic relationships are natural for teenagers because they are an important part of their development, which can play a role in the formation of personality. The development of knowledge, skills, and experience that needed to form romantic relationships as well as healthy and positive sexuality is a process throughout the life span (van de Bongardt, Yu, Dekovic, \& Meeus, 2015). In particular, adolescents and young adults are prominent developmental periods for the exploration of romantic relationships and sexual behavior (Collins et al., 2009). So that it becomes easily accepted when teenagers have begun to have romantic feelings for the opposite sex and carry out activities in the context of romantic relationships.

The aim of getting to know closer the characteristics of the opposite sex and making it a part of the effort to prepare for the future shows that romantic relationships in Balinese adolescents, are important and decisive phases for their subsequent development. This goal seems to be related to a number of attitudes that are considered important in a relationship.

When Balinese adolescents view romantic relationships also from the point of view of possible impacts, this shows a reflection of their experiences and observations of events around them or based on their values. Positive impacts or benefits obtained from a romantic relationship, such as increasing academic motivation, maturing personality, and obtaining comfort and calm in life; while the attribution process that occurs is when teens process to understand the reasons behind the actions taken by the couple and the reason for the conflict in their relationship. Through this process adolescent become more mature figures because they learn to manage their egos. Activities carried out are also important characteristics of a romantic relationship. Disclosure of feelings is the most important part when adolescent wants to start a relationship and then this is expressed with behaviors and activities that are romantic with a partner. Intimate physical contacts with romantic partner distinguish this relationship from the other interactions. 
Manning et al. (2000) argues that romantic relations are a typical context in which adolescent sexual behavior emerges. Physical contact mentioned as part of the concept of Balinese remembrance of romantic relations is kissing and hugging. In the context of terms used to represent romantic relations, the words mecekle and Teman Rasa Istri, which refer to the context of more intimate sexual interactions, appear. In this regard, the findings on the concept of romantic relations from Balinese adolescents' perceptions can be used as a basis for studies that also cover Balinese adolescents' actual experiences and behaviors in romantic relationships. Some terms representing romantic relationships with their respective meanings indicate that the scope or range of understanding of Balinese adolescents is quite extensive. Although they express the notion of romantic relationships that are relatively similar, but with a number of terms with diverse meanings, researchers need to consider making a classification of the forms of romantic relations with their respective characteristics.

Furman and Wehner (1994) offer a behavioral systems approach to understanding adolescent romance's developmental tasks. The systems invoked in adolescent romantic relationships are affiliative, sexual/reproductive, attachment, and caregiving. In this behavioral systems approach, the affiliative function of adolescent romantic relationships offers companionship, reciprocity, and cooperation. The concept of romantic relations from Balinese adolescents' perceptions includes the existence of this affiliative system which is indicated by the importance of meeting companionship needs for romantic couples through intensive interaction and certain attitudes to support partner togetherness, such as commitment to listen and always there for each. Feelings, attitudes, and behaviors that arise in romantic relationships must be reciprocal that both parties should give each other an equal effort and work together to maintain relationships.

The sexual/ reproductive system includes physical intimacy and the potential for procreation. As stated earlier, romantic relationships are common in which sexual behavior arises. The data above shows that one of the activities that characterize romantic relationships is physical contact, such as hugs and kisses. Balinese adolescents identify that physical intimacy is also a differentiator with other forms of relations, such as friendship relations. The attachment system includes love, closeness, bonding, and feelings of security. Feelings of love and affection are common reasons for starting a romantic relationship. Through agreement on how the relationship is done, couples establish emotional and physical closeness, and have bonds with each other. Feelings of security arise as a result of closeness that occurs between partners. The caregiving system is represented by support and assistance between partners. Support and assistance appear as part of the psychomotor dimension in the concept of Balinese adolescents' romantic relations, for example, in terms of academics and in daily life. Furman and Wehner (1994) suggest that the affiliative and sexual/reproductive systems are active in adolescent romance before the attachment and caregiving systems. These latter two systems may not manifest until early adulthood. This model also suggests that systems are engaged in a cumulative fashion rather than a progression where one system gives way to another. For example, when the attachment system is active in a relationship, the sexual/reproductive and affiliative systems are probably also active.

The concept of romantic relations from Balinese adolescents' perception fulfills the behavioral system proposed by Furman and Wehner (1994) as described above. On the other hand, the responses obtained in this study are quite diverse although they have quite similar meanings. To be able to formulate the definition of romantic relations in Balinese teenagers it seems that it requires a longer process. Now we will try to compare the 
findings of this study with the definition of the concept of romantic relations proposed by Collins et al. (2009) and Brown's definition.

According to the two experts, the components in the concept of romantic relations are that relations are mutual, dyadic, voluntary, generally involving expressions of affection and the existence of sexual components. In more detail, Brown et al. (1999) proposed the existence of affiliation, intimacy, and companionship. Whereas Collins et al. (2009) add the difference in intensity of interactions compared to other relationships. Balinese adolescents' concept of romantic relations thoroughly fulfills all the components in the two experts' definition. The nature of mutual and voluntary relationships underlying with the expression positive emotions, and negative emotions that arise as a result of the depth of relationships. So behaviors and joint activities are considered important in romantic relationships and the presence of physical contact that leads to sexual behavior. As explained at the beginning of this article, efforts to understand romantic relationships need to be linked to the cultural conditions of the society in which adolescents develop. The romantic relationship that is perceived as a special relationship is formed voluntary, committed, and provides opportunities for adolescents to develop positive feelings that can support their readiness for the next developmental stage, seems to be in line with Balinese cultural values that guide attitudes and behavior of Balinese to develop harmonious relationship with each other. On the other hand, the conceptualization of romantic relationships that refers to the involvement of physical contact that leads to sexual behavior with a romantic partner, shows internalization of values that are not in line with Balinese culture. As previously explained, Balinese youth as part of the global community receive external cultural influences through their involvement with the development if information technology. This dynamic is seen as the consequence of modernization. For example, through modeling on television personalities, adolescents could form opinion about violence, sex, roles, and relationships, and feelings of being connected to a wider network of peers who are united with different types of values and interests. Since adolescence is the period of biological changes, there has been an increase in sexual tendencies so that viewing sexual content could trigger sexual behavior (Panahi, 2015).

As the first research to explore the concept of romantic relationship of Balinese adolescents, this research has a number of limitations, such as that the emergent themes reported from a group of respondents who had not been classified based on demographic variables such as age group, gender, socioeconomic background, or the characteristics of the living area. Other variables that also seem important to be deepened the conceptualization of romantic relationships are those related to the experiences of establishing romantic relationships that include the age of starting first relation, the frequency, and the length of the relation. With those considerations, the conceptualization of Balinese adolescents' romantic relationship will be more comprehensive.

The limitation of this study's results is that it still takes a lot of effort to formulate a satisfying definition of romantic relationships. This study also does not describe the differences in the concept of romantic relationships in terms of gender, age group characteristics, socioeconomic, and other demographic aspects. Another limitation of this research is that it has not yet discussed the cultural values that might influence Balinese adolescents' perceptions of romantic relationships and the extent to which culture shapes these perceptions. 


\section{Conclusion and Recommendation}

\section{Conclusion}

Balinese adolescents perceive romantic relationships as an exclusive relation that involves more intense and complicated affective dimensions, purposeful, and impactful to their development. They characterize with some contents such as romantic activities with the romantic partner. This formulation is compatible with some of the previous theories related to romantic relationships, which are often used to understand the dynamics of these relationships among adolescents. The nature of reciprocal and voluntary relationships that are based on the expression of positive emotions and negative emotions appears as a result of the seriousness of the relationship. Thus, enabling joint behaviors and activities that are considered important in romantic relationships such as physical contact, can lead to sexual behavior.

The terms representing romantic relationships in Balinese adolescents' daily lives are an interesting finding to explore more. Many kinds of terms with its own meaning showed that romantic relationships have a wide range of characteristics. These terms have their respective meanings that are quite diverse and will be interesting if used to categorize the types of romantic relationship in Balinese adolescents.

Finally, these findings showed us that the formulation of romantic relationships would never be apart from the individuals' perception related to their experiences and comprehensions. To understand the dynamics of adolescent attitudes and behavior in the context of a love relationship, namely by exploring their opinion about the relationship.

\section{Recommendation}

This study showed that the concept of romantic relations for each individual from the same cultural group could be very diverse because it was the result of different understandings and experiences. This study's findings can provide an initial understanding of the concept of romantic relationships perceived by Balinese adolescents. These findings can provide a stepping stone for further research on a romantic relationship in Balinese society because it presents experiences and what is in the minds of adolescents in the form of definitions of romantic relations. It can also use as a basic to make some kinds of policy on education, especially in healthy relationships and sexual education for adolescents. This approach could support adolescents in perceiving romantic relationships as valuable experiences for their psychological development positively.

Further studies need to emphasize more about the influence of culture on the forms of adolescent behavior or activity in romantic relationships. The influence of values in society is also interesting to study to understand romantic relations in Balinese society.

\section{References}

Barton, A. W., Hurt, T. R., Futris, T. G., Sheats, K. F., McElroy, S. E., \& Landor, A. M. (2017). Being committed: conceptualizations of romantic relationship commitment among low-income African Americans adolescents. Journal of Black Psychology, 43, 111-134.

Blackwood, E. (2000). Culture and women's sexualities. Journal of Social Issues, 56, 223-238. Doi: 10.1111/0022-4537.00162. 
Blair, S.L. \& Madigan, T.J. (2016). Dating attitudes and expectations among young Chinese adults: an examination of gender differences. The Journal of Chinese Sociology, 3(2), 1-19. Doi: 10.1186/s40711-016-0034-1.

Braun, V. \& Clarke, V. (2006). Using thematic analysis in psychology. Qualitative Research in Psychology, 3(2), 77-101. Doi: 10.1191/1478088706qp063oa.

Boislard, M.A., van de Bongardt, D., \& Blais, M. (2016). Sexuality (and lack there of) in adolescence and early adulthood: a review of the literature. Behavioral Sciences, 6(1), 1-24. Doi: 10.3390/bs6010008.

Brown, B. B., Feiring, C., \& Furman, W. (1999). Missing the love boat: Why researchers have shied away from adolescent romance. In W. Furman, B. B. Brown, \& C. Feiring (Eds.), The development of romantic relationships in adolescence (pp. 116). New York, NY: Cambridge University Press.

Cavanagh, S. E. (2007). The social construction of romantic relationships in adolescence: Examining the role of peer networks, gender, and race. Sociological Inquiry, 77(4), 572-600. Doi: 10.1111/j.1475-682X.2007.00207.x.

Collins, W. A. (2003). More than myth: the developmental significance of romantic relationships during adolescence. Journal of research on adolescence, 13(1), 1-24. Doi: 10.1111/1532-7795.1301001.

Collins, W.A., Furman, W., \& Welsh, D.P. (2009). Adolescent Romantic Relationships. Article in Annual Review of Psychology, February 2009. Doi: 10.1146/annurev.psych.60.110707.163459.

Collins, W. A., \& Madsen, S. D. (2006). Personal relationships in adolescence and early adulthood. In A. L. Vangelisti \& D. Perlman (Eds.), The Cambridge handbook of personal relationships (pp. 191-209). New York, NY: Cambridge University Press.

Concept System, Inc. (2014). Teen dating Relationships: Udnerstanding and Comparing Youth and Adult Conceptualizations, Final Report. National Institute of Justice Office of Justice Programs, U.S. Department of Justice.

Connoly, J. \& McDonald, K.P. (2020). Cross-Cultural Perspectives on Dating and Marriage. In S. Hupp \& J.D. Jewell (Eds.), The Encyclopedia of Child and Adolescent Development. John Willey \& Sons, Inc.

Dharmayuda, I. M. S. (1995). Kebudayaan Bali: Pra-Hindu, Masa Hindu, dan Pasca Hindu. Denpasar: Kayumas Agung.

Davis, K. E., \& Todd, M. J. (1982). Friendship and love relationships. In K. Davis (Ed.), Advances in descriptive psychology, Vol. 2 (pp. 79-122). Greenwich, CT: JAI Press.

Dhariwal, A., \& Connolly, J. (2013). Romantic experiences of homeland and diaspora south asian youth: westernizing processes of media and friends. Journal of Research on Adolescence, 23(1), 45-56. Doi: https://doi.org/10.1111/j.15327795.2012.00803.x.

Eurazmi. (2018). Survei kisara ungkap perilaku seks remaja Denpasar usia 11-15 tahun sudah berhubungan intim. Retrieved: https://bali.tribunnews.com/2018/12/06/survei-kisara-ungkap-perilaku-seksremaja-denpasar-usia-11-15-tahun-sudah-berhubungan-intim.

Furman, W., L., \& Shaffer. (2003). The role of romantic relationships in adolescent development. In P. Florsheim (Ed.), Adolescent romantic relations and sexual behavior: Theory, research, and practical implications (pp.3-22). Mahwah, NJ: Lawrence Erlbaum Associates.

Furman, W., \& Shoemaker, L.B. (2008). Patterns of interaction in adolescent romantic relationships: distinct features and links to other close relationships. Journal of 
Adolescence. 2008 December; 31(6), 771-788. Doi: 10.1016/j.adolescence.2007.10.007.

Furman, W., \& Wehner. E.A. (1994). Romantic views: toward a theory of adolescent romantic relationships. in Personal Relationships during Adolescence, $\mathrm{R}$. Montemayor, G. R. Adams, and T. P. Gullotta (Eds.). Thousand Oaks, CA: Sage.

Giordano P, Manning W, \& Longmore M. (2005). The romantic relationships of AfricanAmerican and white adolescents. Sociological Quarterly, 46(3), 545-568. Doi: 10.1111/j.1533-8525.2005.00026.x.

Hertlein, K. M. (2012). Digital dwelling: technology in couple and family relation- ships. Family Relations, 61(3), 374-387. Doi:10.1111/j.1741-3729.2012.00702.x.

Hochschild, A. R. (1979). Emotion work, feeling rules, and social structure. American Journal of Sociology, 85(3), 551-575. Doi: 10.1086/227049.

Hyman, M.R., \& Sierra, J.J. (2016). Open-versus close-ended survey questions. Business Outlook, 14(2), 1-5.

Jackson, S.M. (1999). Issues in the dating violence research: a review of the literature. Aggression and Violent Behavior, 4(2), 233-247. Doi: 10.1016/S13591789(97)00049-9.

Kabir, S.M.S. (2016). Basic Guidelines for Research: An Introductory Approach for All Disciplines. Bangladesh: Book Zone Publication.

Karabanova, O.A. \& Poskrebysheva, N.N. (2013). Adolescent autonomy in parent-child relations. Procedia - Social and Behavioral Sciences, 86, 621-628. Doi: https://doi.org/10.1016/j.sbspro.2013.08.624.

Karney, B.R., M.K. Beckett, R.L. Collins, R.N. \& Shaw. (2007). Adolescent romantic relationships as precursors of healthy adult marriages. A review of theory, research and programs. RAND Labor and Population. Doi: 10.7249/TR488.

Kartika, A.A.D. \& Budisetyani, I.G.A. (2018). Hubungan pola asuh demokratis dengan perilaku seksual pranikah pada remaja di Denpasar dan Badung. Jurnal Psikologi Udayana, 5(1), 63-71. ISSN: 23545607.

Kuperburg, A, \& Padgett, J. E. (2015). Dating and hooking up in college: Meeting contexts, sex, and variation by gender, partner's gender, and class standing. Journal of Sex Research, 52(5), 517-531. Doi: 10.1080/00224499.2014.901284.

Lauren, J., Troy, A.B., \& Carver, C.S. (2005). Two distinct emotional experiences in romantic relationships: effects of perceptions regarding approach of intimacy and avoidance of conflict. PSPB, 31(8), 1123-1133. Doi: 10.1177/0146167205274447.

Maguire, M., \& Delahunt, B. (2017). Doing a thematic analysis: a practical, step-by-step guide for learning and teaching Scholars. AISHE-J 8(3), 3351-33514.

Manning, W. D., Longmore, M. A., \& Giordano, P. C. (2000). The relationship context of contraceptive use at first intercourse. Family Planning Perspectives, 32(3), 104110. DOI: $10.2307 / 2648158$.

Panahi, S. (2015). Impact of Moderinzation on Development of Adolescents The Media, Culture, Technology. Unique Journal of Pharmaceutical and Biological Sciences, $3(2), 15-22$.

Reja, U., Manfreda, K.L., Hlebec, V., \& Vehovar, V. (2003). Open-ended vs. Closeended Questions in Web Questionnaires. Development in Applied Statistics. Ferligoj, A., Mrvar, A. (Eds.). Ljubljana: FDV.

Royer, H.R., Keller, M.L., \& Heidrich, S.M. (2009). Young adolescents' perceptions of romantic relationships and sexual activity. Sex Education, 9(4), 395-408. DOI: 10.1080/14681810903265329. 
Sarantakos, S. (2005). Social research (3rd ed.). Basingstoke, UK: Palgrave Macmillan. Seiffge-Krenke, I., Bosma, H., Chau, C., C , ok, F., Gillespie, C., Loncaric, D., Molinar, R., Cunha, M., Veisson, M., \& Rohail. I. (2010). All the need is love? Placing romantic stress in the context of other stressors: A 17-nation study. International Journal of Behavioral Development, 34(2), 106-112. Doi: https://doi.org/10.1177\%2F0165025409360290.

Soller, B., Haynie, D.L., \& Kuhlemier, A. (2016). Sexual intercourse, romantic relationship inauthenticity, and adolescent mental health. Social Science Research, 64, 237- 248. Doi:10.1016/j.ssresearch.2016.10.00.

Ting-Toomey, S., \& Dorjee, T. (2019). Communicating across cultures. (2nd ed.). The Guildford Press.

Tskhay, K.O., \& Rule, N.O. (2014). Sexual Orientation Across Culture and Time. Psychology of Gender and Culture. Safdar, S. \& Kosakowska-Berzecka, N. (Eds.). Springer Publishing.

Vaterlaus, J.M., Tulane, S., Porter, B.D., \& Beckert, T.E. (2018). The perceived influence of media and technology on adolescent romantic relationships. Journal of Adolescent Research, 33(6), 651-671. Doi: https://doi.org/10.1177/074355841771261.

van de Bongardt, D., Yu, R., Dekovic, M., \& Meeus, W.H.J. (2015). Romantic relationships and sexuality in adolescence and young adulthood: The role of parents, peers, and partners. European Journal of Developmental Psychology, 12(5), 497-515. Doi: 10.1080/17405629.2015.1068689.

van Eeuwijk, P., \& Zuzanna, A. (2017). How to ... Conduct a Focus Group Discussion (FGD). Methodological Manual. Basel: University of Basel.

Widhiyanti, D.A., Yuniarti, K.W., Minza, W.M., \& Riyono, B. (2019). Schwartz's value Tyoes on Romantic Relationships: Exploratory Study on Balinese Society. Proceeding of the International Interdisciplinary Studies Seminar, IISS 2019. Doi: 10.4108/eai.23-10-2019.2293049.

Wijaya, I.M.K., Giri, M.K.W., Wahyuni, N.P.D., \& Setiawan, K.H. (2018). Premarital Sex Behavior of Teenagers: A Case in Bali, Indonesia. International Journal of Health Sciences, 2(3), 11-21. Doi: 10.29332/ijhs.v2n3.211.

Whittecar, W.A. (2019). Late Adolescent Perceptions of Romantic Relationships and Romantic Experiences. Theses. Montana State University. 